\title{
MENINGKATKAN KAPABILITAS PROSES PADA SISTEM PENDUKUNG PENGAMBILAN KEPUTUSAN (DSS) MENGGUNAKAN COBIT 4.1
}

\author{
Dian Nurdiana, M.Kom.
}

\begin{abstract}
ABSTRAK
Decision support system (DSS) merupakan sebuah sistem yang berfungsi untuk memberikan rekomendasi dalam pengambilan keputusan, oleh karena itu kemampuan atau kapabilitas dari sistem harus bisa mendukung terhadap kebutuhan bisnis. UNIVERSITAS $X$ merupakan universitas yang sudah menggunakan sistem ini dalam pengelolaan proses bisnis yang ada diorganisasi, namun dalam pengelolaanya terdapat beberapa permasalahan yang dapet mengganggu kinierja dari DSS tersebut. Oleh karena itu butuh sebuah model yang bisa meningkatkan kapabilitas IT sehingga bisa meningkatkan kinerja dari DSS tersebut. Model pengukuran COBIT 4.1 menggunakan metode Process Assessment Model merupakan salah satu model yang digunakan untuk meningkatkan kapabilitas proses IT, model ini mendukung penilaian kapabilitas kinerja tata kelola teknologi informasi dengan menyediakan indikator sebagai pedoman dalam interpretasi tujuan proses dan keluaran yang didefinisikan dalam COBIT 4.1 dan atribut proses yang didefinisikan dalam ISO/IEC 15504 dengan pengukuran kapabilitas didasarkan pada sembilan atribut proses, kesembilan atribut di atas terdapat dalam level-level kapabilitas proses dan harus dipenuhi untuk mencapai suatu level. Dari hasil penelitian ini didapatkan tingkat pencapain kapabilitas proses pada DSS di UNIVERSITAS $X$, kemudian memberikan rekomendasi untuk bisa menyelesaikan permasalahan yang sedang dihadapi dan rekomendasi untuk meningkatkan level kapabilitas proses berdasarkan COBIT 4.1 menggunakan metode Process Assessment Model.
\end{abstract}

Kata Kunci: Decision Support System (DSS), Cobit 4.1, Assessment Model, Kapabiltias Proses.

\section{Pendahuluan}

Sistem pendukung pengambilan keputusan (Decision Support System) adalah salah satu perkembangan sistem informasi saat ini yang sedang banyak dikembangkan oleh beberapa organisasi. Dengan dikembangkannya DSS ini bertujuan membantu pimpinan dalam melakukan perencanaan dan analisa evaluasi diri dengan lebih baik dan pengambilan keputusan yang lebih obyektif. Sehingga dengan adanya DSS ini akan mempercepat pimpinan dalam menganalisis dan mengambil keputusan baik terhadap perubahan pasarar maupun keputusan lainnya.

Dalam penelitian ini menggunakna nama Universitas $X$ sebagai tempat penelitian studi kasus, hal ini dimaksudkan untuk menjaga kerahasiaan pada Universitas yang sebenarnya. Universitas $X$ merupakan salah satu universitas yang sudah mengembangkan dan mengimplementasikan sistem informasi untuk membantu dalam menyelaraskan proses bisnis agar bisa mencapai tujuan organisasi dengan cepat. Sistem informasi ini dibangun dan dikelola oleh suatu divisi yang khusus pengelolaan sistem informasi dan komputerisasi dilingkungan Universitas $X$. Salah satu sistem yang sedang dikelola dan dikembangkan saat ini adalah sistem pendukung pengambilan keputusan (Decision Support System) atau kita singkat dengan DSS.

Menurut divisi yang mengelola sistem informasi di Universitas $X$, DSS merupakan sistem yang benar-benar dibutuhkan oleh lembaga saat ini. Oleh karena itu pada saat ini mereka fokus dalam mengembangkan DSS agar bisa membantu dalam pengambilan keputusan. Salah satu DSS yang sudah digunakan dan akan dikembangkan adalah sistem penilaian dosen dan sistem penilaian kepegawaian. Namun dalam pengelolaannya ternyata terdapat beberapa permasalah yang muncul diantaranya adalah perubahan kebijakan dan data yang digunakan dalam mengambil keputusan. Hal ini menjadi sangat penting dalam DSS karena ketika aturan berubah maka berpengaruh terhadap hasil dan kinerja dari sistem.

Dari permasalan diatas maka perlu pengelolaan yang mampu menyelesaikan permasalahan-permasalah yang terjadi saat ini. Dengan menyelesaikan permasalah-permasalah tersebut diharapkan bisa meningkatkan kualitas maupun kinerja dari sistem pendukung pengambilan keputusan atau DSS di UNIVERSITAS X. Cobit 4.1 Process Assesment Model merupakan salah satu model yang berisi kerangka dasar dari proses pengelolaan IT. Model ini memberikan penilaian sejauh mana pencapaian kapabilitas proses yang telah dilakukan oleh UNIVERSITAS $\mathrm{X}$ dalam mengimplementasikan sistem pendukung pengambilan keputusan atau DSS. Setelah mengetahui posisi pencapaian kapabilitas proses, kemudian kita bisa merekomendasikan bagaimana cara menyelesaikan permasalahan dan menaikan level kapabilitas proses dari DSS. Karean semakin baik level kapabilitas proses yang dicapai maka kinerja dan pengelolaan dari sistem pendukung pengambilan keputusan di UNIVERSITAS $X$ akan lebih baik.

Berdasarkan latar belakang diatas maka penulis bermaksud membuat penelitan yang berjudul "Meningkatkan Kapabilitas Proses Pada Sistem Pengambilan Keputusan (DSS) Menggunakan Cobit 4.1".

\section{2. $\quad$ COBIT 4.1}

Control Objective for Information \& Related Technology (COBIT) adalah sekumpulan dokumentasi best practice untuk IT Governance yang dapat membantu auditor, pengguna (user), dan manajemen, untuk menjembatani gap antara resiko bisnis, kebutuhan kontrol dan masalah-masalah teknis IT (Sasongko, 2009). COBIT mendukung tata kelola TI dengan menyediakan kerangka kerja untuk mengatur keselarasan TI dengan bisnis. Selain itu, kerangka kerja juga 
memastikan bahwa TI memungkinkan bisnis, memaksimalkan keuntungan, resiko TI dikelola secara tepat, dan sumber daya TI digunakan secara bertanggung jawab (Tanuwijaya dan Sarno, 2010). COBIT merupakan standar yang dinilai paling lengkap dan menyeluruh sebagai framework IT audit karena dikembangkan secara berkelanjutan oleh lembaga swadaya profesional auditor yang tersebar di hampir seluruh negara. Dimana di setiap negara dibangun chapter yang dapat mengelola para profesional tersebut.

COBIT mengidentifikasi 34 proses teknologi informasi yang dikelompokkan menjadi empat domain utama, yaitu:

1. Plan and Organise (PO)

2. Acquire and Implement (AI)

3. Deliver and Support (DS)

4. Monitor and Evaluate (ME)

\section{Pengukuran Pada Cobit 4.1}

\subsection{Maturity Model}

Model kematangan (Maturity Model) digunakan sebagai alat untuk melakukan benchmarking dan self-assessment oleh manajemen teknologi informasi secara lebih efisien. Model kematangan untuk pengelolaan dan kontrol pada proses teknologi informasi didasarkan pada metoda evaluasi perusahaan atau organisasi, sehingga dapat mengevaluasi sendiri, mulai dari level 0 (non-existent) hingga level 5 (optimised).
0. Non-existent
1. Initial/ad-hoc
2. Repeatable but Intuitive
3. Defined Process
4. Manage and Measurable
5. Optimised

Beberapa cara yang umum dilakukan dalam melaksanakan penilaian maturity diantaranya adalah (Guldentops, 2003):

1. Pendekatan multidisiplin kelompok orang yang mendiskusikan dan menghasilkan kesepakatan level maturity kondisi sekarang,

2. Dekomposisi deskripsi maturity menjadi beberapa pernyataan sehingga manajemen dapat memberikan tingkat persetujuannya,

3. Penggunaan atribut matriks sebagaimana didokumentasikan dalam COBIT'sManagement Guidelines dan memberikan nilai masing-masing atribut dari setiap proses.

\subsection{Process Assessment Model}

Metode COBIT 4.1 Process Assessment Model mendukung penilaian kapabilitas kinerja tata kelola teknologi informasi dengan menyediakan indikator sebagai pedoman dalam interpretasi tujuan proses dan keluaran yang didefinisikan dalam COBIT 4.1 dan atribut proses yang didefinisikan dalam ISO/IEC 15504. Pengukuran kapabilitas didasarkan pada sembilan atribut proses. Kesembilan atribut di atas terdapat dalam level-level kapabilitas proses dan harus dipenuhi untuk mencapai suatu level, yaitu [British Standard, 20032004].

0. Incomplete process
1. Performed process

2. Managed process

3. Established process

4. Predictable process

5. Optimizing process

Penilaian dengan menggunakan COBIT 4.1 Process Assessment Model menggunakan dua tipe indikator penilaian, yaitu [ISACA, 2011]:

1. Process capability indicators, yang digunakan pada kapabilitas level 1 sampai 5. Process capability indicators yang digunakan antara lain:

1) Generic practice (GP)

2) Generic work product (GWP)

2. Process performance indicators, yang digunakan hanya pada kapabilitas level 1, antara lain base practices dan work products.

Indikator kinerja proses (Base Practice dan Work Products) untuk setiap proses dan digunakan untuk menentukan apakah suatu proses berada pada kapabilitas tingkat 1. Base Practice dan Work Products untuk setiap proses terdapat pada COBIT 4.1. Sedangkan Generic practice dan Generic work product digunakan untuk menentukan level kapabilitas proses antara level 1 sampai dengan level 5 .

Dalam melakukan pengukuran, setiap atribut pada tiap level juga harus diberikan rating dengan skala sebagai berikut [ISACA, 2011]:

Tabel 1 Skala Pencapaian Kapabilitas

\begin{tabular}{|l|l|}
\hline Skala & Pencapaian \\
\hline $0 \%-15 \%$ & Not Achieved \\
\hline $15 \%-50 \%$ & Partially Achieved \\
\hline $50 \%-85 \%$ & Largely Achieved \\
\hline $85 \%-100 \%$ & Fully Achieved \\
\hline
\end{tabular}

Sebuah proses dapat dinyatakan mencapai tingkatan kapabilitas tertentu apabila seluruh atribut yang ada pada tingkat tersebut memiliki rating "Fully Achieved" atau "Largely Achieved", dengan seluruh atribut pada tingkat di bawahnya memiliki rating "Fully Achieved" [Duncan, 2002].

\subsection{Perbandingan Maturity Model dan Process Assessment} Model

Beberapa hal yang membedakan COBIT 4.1 Maturity Model dengan COBIT 4.1 Process Assessment Model antara lain [A. P. Marina, 2012]:

1. COBIT 4.1 Process Assessment Model adalah pengukuran berdasarkan ISO/IEC 15504 yang baru digunakan pada COBIT 4.1 dan COBIT 5. Metode ini digunakan karena permintaan pasar yang membutuhkan metode pengukuran kapabilitas teknologi informasi yang lebih tepat, akurat, dan dapat diandalkan daripada yang sebelumnya, yaitu COBIT 4.1 Maturity Model.

2. COBIT 4.1 Process Assessment Model berdasarkan ISO/IEC 15504 menggunakan skala dan istilah pengukuran yang berbeda dari COBIT 4.1 Maturity Model. Hal ini dapat dilihat pada Tabel 2.4. 
Tabel 2 Perbandingan Matury Modem Dan Process Assessment Model

\begin{tabular}{|c|c|c|}
\hline \multirow{2}{*}{$\begin{array}{l}\text { Tingkat } \\
\text { Kematangan pada } \\
\text { Maturity Model } \\
\end{array}$} & \multicolumn{2}{|c|}{ Tingkat Kapabilitas pada ISO/IEC 15504} \\
\hline & Level Kapabilitas & Attribute \\
\hline 5- Optimised & 5- Optimizing & $\begin{array}{l}\text { PA.5.1 Process } \\
\text { Innovation } \\
\text { PA } 5.2 \text { Process } \\
\text { Optimization } \\
\end{array}$ \\
\hline $\begin{array}{l}\text { 4- Manage and } \\
\text { Measurable }\end{array}$ & 4- Predictable & $\begin{array}{l}\text { PA.4.1 Process } \\
\text { Measurement } \\
\text { PA 4.2 Process Control }\end{array}$ \\
\hline 3- Defined Process & 3-Established & $\begin{array}{l}\text { PA.3.1 Process } \\
\text { Definition } \\
\text { PA 3.2 Process } \\
\text { Deployment }\end{array}$ \\
\hline $\mathrm{N} / \mathrm{A}$ & 2-Managed & $\begin{array}{l}\text { PA.2.1 Performance } \\
\text { Management } \\
\text { PA2.2 Work Product } \\
\text { Management }\end{array}$ \\
\hline $\mathrm{N} / \mathrm{A}$ & 1-Performed & $\begin{array}{l}\text { PA.1.1 Process } \\
\text { Performance }\end{array}$ \\
\hline $\begin{array}{l}\text { 2- Repeatable } \\
\text { 1- Initial / Ad-Hoc } \\
\text { 0- Non-existent }\end{array}$ & O-Incomplete & \\
\hline
\end{tabular}

3. Pada COBIT 4.1 Process Assessment Model, ketercapaian suatu level diukur berdasarkan ketercapaian atribut yang ada pada level tersebut dan level sebelumnya. Ketercapaian atribut proses diukur berdasarkan bukti-bukti yang ada yang terdiri dari aktivitas dan dokumen yang telah terdefinisi. Pengukuran dengan menggunakan COBIT 4.1 Process Assessment Model biasanya menghasilkan hasil yang lebih rendah dari COBIT 4.1 Maturity Model. Hal ini disebabkan pengukuran dengan COBIT 4.1 Process Assessment Model menggunakan pendekatan inkremental, yaitu atribut pada level rendah harus sepenuhnya dipenuhi sebelum level yang lebih tinggi dapat dicapai. Hal-hal di atas mengakibatkan COBIT 4.1 Process Assessment Model memiliki hasil pengukuran yang lebih tepat, akurat, objektif, dan dapat diandalkan.

\section{Hasil Penelitian Dan Pembahasan}

3.1 Pemetaan IT Goals (Target Pencapaian) Dengan IT Goals pada Cobit 4.1.

Untuk memfokuskan penelitian ini, maka target pencapaian atau IT Goal UNIVERSITAS $X$ yang akan diukur dalam penelitian ini adalah Menyusun sistem pendukung pengambilan keputusan (Decision Support System). Tabel 4.5 menunjukan pemetaan dari target pencapaian atau IT Goal UNIVERSITAS X dengan IT Goal pada Cobit 4.1. hasil pemetaan tersebut bertujuan untuk memilih domain mana yang sesuai dengan target pencapaain IT organisasi.

Tabel 4.5 Pemetaan Antara IT Goal UNIVERSITAS X dan IT Goal Cobit 4.1

\begin{tabular}{|l|c|c|cc|}
\hline No & IT Goals UNIVERSITAS X & No & \multicolumn{2}{|c|}{ IT Goal } \\
\hline
\end{tabular}

\begin{tabular}{|c|c|c|c|}
\hline 2 & $\begin{array}{l}\text { Menyusun sistem } \\
\text { pendukung pengambilan } \\
\text { keputusan (Decision } \\
\text { Support System) yang } \\
\text { membantu pimpinan } \\
\text { dalam melakukan } \\
\text { perencanaan dan analisa } \\
\text { evaluasidiri dengan lebih } \\
\text { baik dan pengambilan } \\
\text { keputusan yang lebih } \\
\text { obyektif. }\end{array}$ & 6 & $\begin{array}{l}\text { Menentukan } \\
\text { bagaimana } \\
\text { kebutuhan fungsi } \\
\text { dan pengendaian } \\
\text { bisnis diterjemahkan } \\
\text { ke dalam solusi } \\
\text { otomatis yang efektif } \\
\text { dan efisien. }\end{array}$ \\
\hline
\end{tabular}

Setelah melakukan pemetaan antara IT goal UNIVERSITAS $X$ dan IT goal Cobit 4.1 diperoleh IT Goal nomor 6 pada Cobit 4.1. Selanjutnya adalah menghubungkan antara IT goal dengan proses yang sesuai berdasarkan Cobit 4.1. Tabel 4.6 dibawah ini menunjukan nomor proses yang sesuai dengan IT goal Cobit 4.1.

Tabel 3 Pemetaan IT Goal Dengan Proses

\begin{tabular}{|l|l|l|}
\hline No & IT Goals Cobit 4.1 & Proses \\
\hline 6 & $\begin{array}{l}\text { Menentukan bagaimana kebutuhan } \\
\text { fungsi dan pengendaian bisnis } \\
\text { diterjemahkan ke dalam solusi otomatis } \\
\text { yang efektif dan efisien. }\end{array}$ & Al6. dan \\
\hline
\end{tabular}

\subsection{Analisis Hasil Pengumpulan Data}

Pada COBIT 4.1 Process Assessment Model, ketercapaian suatu level diukur berdasarkan ketercapaian atribut yang ada pada level tersebut dan level sebelumnya. Berdasarkan aturan pada ISO/IEC 15504, ketercapaian level 2 dapat diukur apabila level 1 telah terpenuhi dan atribut pada level 1 telah mencapai rating "Fully Achieved". Ketercapaian level 3 dapat diukur bila level 2 terpenuhi dan semua atribut pada level 2 telah mencapai rating "Fully Achieved". Hal ini berlaku pula untuk level-level selanjutnya. Namun, pada penelitian ini, akan dilakukan pengukuran untuk semua level pada kapabilitas proses sehingga seluruh kuesioner akan diberikan untuk pengumpulan data. Hal ini untuk mengetahui ketercapaian seluruh level pada pengelolaan sistem pendukung pengambilan keputusan di UNIVERSITAS $X$.

\section{Pengukuran Ketercapaian Pada Level 1}

\begin{tabular}{|r|r|r|r|r|r|r|r|r|r|r|r|r|}
\hline \multirow{2}{*}{ Nomor Soal } & \multicolumn{7}{|c|}{ Rekapitulasi Jawaban } & \multicolumn{7}{|c|}{ Jumlah } & \multirow{2}{*}{ B } \\
\hline & 1 & 2 & 3 & 4 & 5 & 1 & 2 & 3 & 4 & 5 & & 0.65 \\
\hline 1 & & & 3 & 1 & & 0 & 0 & 9 & 4 & 0 & 13 & 0.6 \\
\hline 2 & & 4 & & & 0 & 0 & 12 & 0 & 0 & 12 & 0.55 \\
\hline 3 & & 1 & 3 & & & 0 & 2 & 9 & 0 & 0 & 11 & 0.55 \\
\hline 4 & 2 & 1 & 1 & & 0 & 4 & 3 & 4 & 0 & 11 & 0.65 \\
\hline 5 & 1 & 1 & 2 & & 0 & 2 & 3 & 8 & 0 & 13 & 0.5 \\
\hline 6 & 2 & 2 & & & 0 & 4 & 6 & 0 & 0 & 10 & 0.55 \\
\hline 7 & 1 & 3 & & & 0 & 2 & 9 & 0 & 0 & 11 & 0.55 \\
\hline 8 & 1 & 3 & & & 0 & 2 & 9 & 0 & 0 & 11 & 0.65 \\
\hline 9 & & 3 & 1 & & 0 & 0 & 9 & 4 & 0 & 13 & 0.6 \\
\hline 10 & & 4 & & & 0 & 0 & 12 & 0 & 0 & 12 & 0.6 \\
\hline 11 & & 4 & & & 0 & 0 & 12 & 0 & 0 & 12 & 0.65 \\
\hline 12 & 1 & 1 & 2 & & 0 & 2 & 3 & 8 & 0 & 13 & 0.65 \\
\hline 13 & 1 & 1 & 2 & 0 & 2 & 3 & 8 & 0 & 13 & $60 \%$ \\
\hline
\end{tabular}

Dari hasil pengukuran pada level 1 berdasarkan jawaban para responden, didapatkan ketercapaian kapabilitas pada level 1 sebesar 
60\%. Nilai tersebut menunjukan skala ketercapaian diposisi Largely Achieved berdasarkan ISO 15504.

\section{Pengukuran Ketercapaian Pada Level 2}

\begin{tabular}{|c|c|c|c|c|c|c|c|c|c|c|c|c|}
\hline \multirow{2}{*}{ Nomor Soal } & \multicolumn{5}{|c|}{ Rekapitulasi Jawaban } & \multicolumn{5}{|c|}{ A } & \multirow{2}{*}{ Jumlah } & \multirow{2}{*}{ B } \\
\hline & 1 & 2 & 3 & 4 & 5 & 1 & 2 & 3 & 4 & 5 & & \\
\hline 1 & & 1 & 2 & 1 & & 0 & 2 & 6 & 4 & 0 & 12 & 0.6 \\
\hline 2 & & & 4 & & & 0 & 0 & 12 & 0 & 0 & 12 & 0.6 \\
\hline 3 & & 1 & 2 & 1 & & 0 & 2 & 6 & 4 & 0 & 12 & 0.6 \\
\hline 4 & & & 4 & & & 0 & 0 & 12 & 0 & 0 & 12 & 0.6 \\
\hline 5 & & 1 & 3 & & & 0 & 2 & 9 & 0 & 0 & 11 & 0.55 \\
\hline 6 & & 1 & 2 & 1 & & 0 & 2 & 6 & 4 & 0 & 12 & 0.6 \\
\hline 7 & & 2 & 2 & & & 0 & 4 & 6 & 0 & 0 & 10 & 0.5 \\
\hline 8 & & & 4 & & & 0 & 0 & 12 & 0 & 0 & 12 & 0.6 \\
\hline 9 & & & 4 & & & 0 & 0 & 12 & 0 & 0 & 12 & 0.6 \\
\hline 10 & & & 4 & & & 0 & 0 & 12 & 0 & 0 & 12 & 0.6 \\
\hline & & & & & & & & & & & Skala $=$ & 0.585 \\
\hline & & & & & & & & & & & Skala $=$ & $59 \%$ \\
\hline
\end{tabular}

Dari hasil pengukuran pada level 2 berdasarkan jawaban para responden, didapatkan ketercapaian kapabilitas pada level 2 sebesar 59\%. Nilai tersebut menunjukan skala ketercapaian diposisi Largely Achieved berdasarkan ISO 15504.

Pengukuran Ketercapaian Pada Level 3

\begin{tabular}{|c|c|c|c|c|c|c|c|c|c|c|c|c|}
\hline \multirow{2}{*}{ Nomor Soal } & \multicolumn{5}{|c|}{ Rekapitulasi Jawaban } & \multicolumn{5}{|c|}{ A } & \multirow{2}{*}{ Jumlah } & \multirow{2}{*}{ B } \\
\hline & 1 & 2 & 3 & 4 & 5 & 1 & 2 & 3 & 4 & 5 & & \\
\hline 1 & & & 4 & & & 0 & 0 & 12 & 0 & 0 & 12 & 0.6 \\
\hline 2 & & 1 & 3 & & & 0 & 2 & 9 & 0 & 0 & 11 & 0.55 \\
\hline 3 & & & 4 & & & 0 & 0 & 12 & 0 & 0 & 12 & 0.6 \\
\hline 4 & & 1 & 3 & & & 0 & 2 & 9 & 0 & 0 & 11 & 0.55 \\
\hline 5 & & 1 & 3 & & & 0 & 2 & 9 & 0 & 0 & 11 & 0.55 \\
\hline 6 & & & 4 & & & 0 & 0 & 12 & 0 & 0 & 12 & 0.6 \\
\hline 7 & & & 4 & & & 0 & 0 & 12 & 0 & 0 & 12 & 0.6 \\
\hline 8 & & & 4 & & & 0 & 0 & 12 & 0 & 0 & 12 & 0.6 \\
\hline 9 & & & 4 & & & 0 & 0 & 12 & 0 & 0 & 12 & 0.6 \\
\hline 10 & & & 4 & & & 0 & 0 & 12 & 0 & 0 & 12 & 0.6 \\
\hline 11 & & 1 & 1 & 2 & & 0 & 2 & 3 & 8 & 0 & 13 & 0.65 \\
\hline & & & & & & & & & & & Skala $=$ & 0.590909091 \\
\hline & & & & & & & & & & & Skala $=$ & $60 \%$ \\
\hline
\end{tabular}

Dari hasil pengukuran pada level 3 berdasarkan jawaban para responden, didapatkan ketercapaian kapabilitas pada level 3 sebesar 60\%. Nilai tersebut menunjukan skala ketercapaian diposisi Largely Achieved berdasarkan ISO 15504.

Pengukuran Ketercapaian Pada Level 4

\begin{tabular}{|r|r|r|r|r|r|r|r|r|r|r|r|r|}
\hline \multirow{2}{*}{ Nomor Soal } & \multicolumn{7}{|c|}{ Rekapitulasi Jawaban } & \multicolumn{7}{|c|}{ Jumlah } & \multirow{2}{*}{ B } \\
\hline & 1 & 2 & 3 & 4 & 5 & 1 & 2 & 3 & 4 & 5 & & 0.6 \\
\hline 1 & & 4 & & & 0 & 0 & 12 & 0 & 0 & 12 & 0.55 \\
\hline 2 & & 1 & 3 & & & 0 & 2 & 9 & 0 & 0 & 11 & 0.6 \\
\hline 3 & 1 & 2 & 1 & & 0 & 2 & 6 & 4 & 0 & 12 & 0.65 \\
\hline 4 & 1 & 1 & 2 & & 0 & 2 & 3 & 8 & 0 & 13 & 0.65 \\
\hline 5 & 1 & 1 & 2 & & 0 & 2 & 3 & 8 & 0 & 13 & 0.6 \\
\hline 6 & & 4 & & & 0 & 0 & 12 & 0 & 0 & 12 & 0.6 \\
\hline 7 & & 4 & & & 0 & 0 & 12 & 0 & 0 & 12 & 0.65 \\
\hline 8 & & 3 & 1 & & 0 & 0 & 9 & 4 & 0 & 13 & 0.6 \\
\hline 9 & & 4 & & & 0 & 0 & 12 & 0 & 0 & 12 & 0.55 \\
\hline 10 & 1 & 3 & & & 0 & 2 & 9 & 0 & 0 & 11 & 0.65 \\
\hline 11 & 1 & 1 & 2 & & 0 & 2 & 3 & 8 & 0 & 13 & 13 \\
\hline
\end{tabular}

Dari hasil pengukuran pada level 4 berdasarkan jawaban para responden, didapatkan ketercapaian kapabilitas pada level 4 sebesar $61 \%$. Nilai tersebut menunjukan skala ketercapaian diposisi Largely Achieved berdasarkan ISO 15504.
Pengukuran Ketercapaian Pada Level 5

\begin{tabular}{|c|c|c|c|c|c|c|c|c|c|c|c|c|}
\hline \multirow{2}{*}{ Nomor Soal } & \multicolumn{5}{|c|}{ Rekapitulasi Jawaban } & \multicolumn{5}{|c|}{ A } & \multirow{2}{*}{ Jumlah } & \multirow{2}{*}{ B } \\
\hline & 1 & 2 & 3 & 4 & 5 & 1 & 2 & 3 & 4 & 5 & & \\
\hline 1 & & 1 & 1 & 2 & & 0 & 2 & 3 & 8 & 0 & 13 & 0.65 \\
\hline 2 & & 1 & 2 & 1 & & 0 & 2 & 6 & 4 & 0 & 12 & 0.6 \\
\hline 3 & & 1 & 2 & 1 & & 0 & 2 & 6 & 4 & 0 & 12 & 0.6 \\
\hline 4 & & 2 & & 2 & & 0 & 4 & 0 & 8 & 0 & 12 & 0.6 \\
\hline 5 & & 1 & 1 & 2 & & 0 & 2 & 3 & 8 & 0 & 13 & 0.65 \\
\hline 6 & & 1 & 3 & & & 0 & 2 & 9 & 0 & 0 & 11 & 0.55 \\
\hline 7 & & 1 & 3 & & & 0 & 2 & 9 & 0 & 0 & 11 & 0.55 \\
\hline 8 & & 1 & 2 & 1 & & 0 & 2 & 6 & 4 & 0 & 12 & 0.6 \\
\hline & & & & & & & & & & & Skala $=$ & 0.60000 \\
\hline & & & & & & & & & & & Skala $=$ & $60 \%$ \\
\hline
\end{tabular}

Dari hasil pengukuran pada level 5 berdasarkan jawaban para responden, didapatkan ketercapaian kapabilitas pada level 5 sebesar $60 \%$. Nilai tersebut menunjukan skala ketercapaian diposisi Largely Achieved berdasarkan ISO 15504

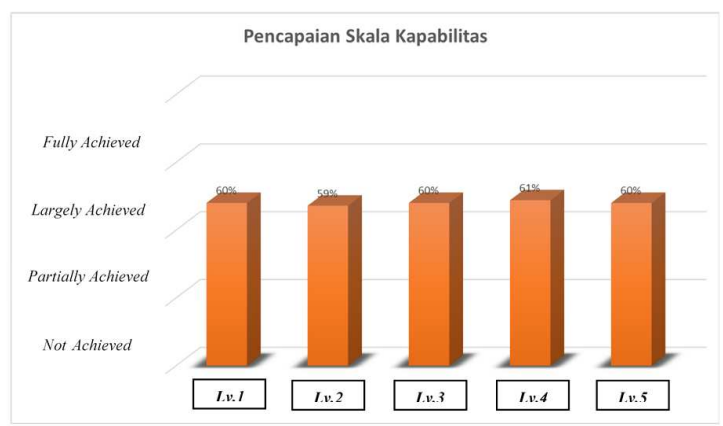

Gambar 4.1 Pencapaian Skala Kapabilitas

Dari hasil pengukuran yang dilakukan untuk level 1 sampai dengan level 5 pada dengan menggunakan COBIT 4.1 Process Assessment Model. Level 1 memiliki ketercapaian sebesar 60\% yang berarti skala ketercapaian diposisi Largely Achieved, Level 2 memiliki ketercapaian sebesar 59\% yang berarti skala ketercapaian diposisi Largely Achieved, Level 3 memiliki ketercapaian sebesar $60 \%$ yang berarti skala ketercapaian diposisi Largely Achieved, Level 4 memiliki ketercapaian sebesar $61 \%$ yang berarti skala ketercapaian diposisi Largely Achieved, Level 5 memiliki ketercapaian sebesar 60\% yang berarti skala ketercapaian diposisi Largely Achieved.

Berdasarkan standar yang ada dalam COBIT 4.1 Process Assessment Model, tata kelola sistem pendukung pengambilan keputusan (DSS) di UNIVERSITAS X (Universitas Komputer Indonesia) telah mencapai tingkat kapabilitas level 1 . Karena pada sebuah proses dapat dinyatakan mencapai tingkatan kapabilitas tertentu apabila seluruh atribut yang ada pada tingkat tersebut memiliki rating "Fully Achieved" atau "Largely Achieved", dengan seluruh atribut pada tingkat di bawahnya memiliki rating "Fully Achieved" [Ducan, 2002].

\subsection{Rekomendasi Untuk Perbaikan}

Pada penelitian ini, rekomendasi yang akan diberikan kepada UNIVERSITAS $X$ untuk pengelolaan sistem pendukung pengambilan keputusan (DSS) akan dibuat kedalam dua tahan. Tahap pertama didalamnya memberikan rekomendasi perbaikan untuk permasalahaan yang sedang terjadi, sedangkan rekomendasi perbaikan untuk tahap kedua dibuat untuk meningkatkan level 
kapabilitas proses dari sistem pendukung pengambilan keputusan (DSS).

\subsubsection{Rekomendasi Untuk Permasalahaan Yang Ada}

1. Meningkatkan kapabilitas proses di level 1 dengan cara memenuhi beberapa base practices dan work products setiap proses yang belum terpenuhi. Pada DSS ini proses yang digunakan pada level 1 antara lain Al1 - Identify Automated Solutions, proses Al2 - Acquire and Maintain Application Software, dan proses Al6 - Manage Changes.

2. Untuk lebih mendetailnya pada level 1 , Organisasi diharapkan bisa memperbaiki dengan melengkapi proses Al1 - Identify Automated Solutions dan A16 - Manage Changes. Karena pada proses Al1 - Identify Automated Solutions mendefinisikan bagaimana mengidentifikasi dari awal kebutuhan bisnis maupun aturan yang digunakan dalam pengembangan SDD, sehingga apabila telah direncana dari awal perubahaanperbuhaan yang muncul dimasa yang akan datang tidak terjadi. Sedang pada proses Al6 - Manage Changes mendefiniskan bagaimana memanajemen perubahaan, sehingga apabila ada perubahaan akan dikelola sehingga perubhaan tersebut tidak berdampak kepada kinerja.

3. Meningkatkan level kapabilitas proses berdasarkan ISO 15504. Dengan meningkatnya level kapabilitas proses diharapakan bisa memperbaiki masalah-masalah yang ada dan bisa menanggulangi permasalahaan yang muncul dimasa yang akan datang.

\subsubsection{Rekomendasi Untuk Menaikan Level}

Rekomendasi yang sebaiknya dilakukan oleh organisasi untuk mengatasi gap tingkat kapabilitas pada sistem pendukung pengambilan keputusan (DSS) antara lain:

1. Rekomendasi langkah perbaikan untuk memenuhi level 1 yang sebaiknya dilakukan adalah:

a. Memenuhi beberapa base practise dan work products yang belum terpenuhi.

b. Membuat perencanaa pengadaan DSS secara detail, jelas, dan menyeluruh.

2. Rekomendasi langkah perbaikan untuk meningkatkan level 1 ke level 2 antara lain:

a. Membuat sasaran dan tujuan yang jelas dari proses untuk pengembangan DSS.

b. Mengawasi sejauh mana kinerja seluruh proses, termasuk menyediakan sumber daya yang dibutuhkan.

c. Menyediakan sumber daya infrastruktur yang dibutuhkan untuk proses, termasuk sumber daya manusia untuk setiap wewenang dan tanggung jawabnya.

d. Menetapkan spesifikasi work product atau dokumen yang harus dibuat terkait proses, serta melakukan pengawasan dan evaluasi terhadap dokumen yang dihasilkan.

3. Rekomendasi langkah perbaikan untuk meningkatkan level 2 ke level 3 antara lain:

a. Membuat prosedur seperti standar kinerja minimum, standar prosedur, persyaratan pelaporan dan pemantauan seluruh proses yang didokumentasikan secara formal dan dikomunikasikan dengan baik. b. Membuat mekanisme pengawasan dan evaluasi untuk memastikan kesesuaian proses yang berjalan dengan prosedur yang telah dibuat.

c. Memastikan adanya sumber daya manusia yang kompeten dalam proses serta mengadakan kegiatan yang dapat meningkatkan kompetensi sumber daya manusia seperti mengadakan pelatihan

d. Membuat standardisasi infrastruktur yang digunakan dalam proses pengelolaan aplikasi yang sesuai dengan kebutuhan.

e. Melakukan analisis data yang didapat dari proses pengawasan terhadap proses yang berjalan untuk memastikan efektivitas prosedur proses dan menentukan peningkatan atau perbaikan terhadap prosedur proses yang sebaiknya dilakukan.

4. Rekomendasi langkah perbaikan untuk meningkatkan level 3 ke level 4 antara lain:

a. Menetapkan informasi yang dibutuhkan dan tujuan pengukuran proses apakah sudah sesuai dengan tujuan bisnis.

b. Membuat mekanisme atau prosedur pengukuran proses secara kualitatif dan kuantitatif secara jelas, terdokumentasi, dan dikomunikasikan dengan baik kepada seluruh pihak yang terkait.

c. Menganalisis hasil pengukuran untuk memantau sejauh mana kinerja DSS telah terpenuh dan mengkarakteristikan kinerja tersebut.

d. Menganalisis dan membuat teknik kontrol yang digunakan untuk mengurangi resiko, kemudian melakukan tindakan apabila terjadi masalah.

5. Rekomendasi langkah perbaikan untuk meningkatkan level 4 ke level 5 antara lain:

a. Menganalisis data-data yang digunakan untuk mengidentifikasi apabila ada yang berpengaruh terhadap kinerja.

b. Menganalisis data-data yang digunakan untuk dingidentifikasi apabila ada inovasi yang bisa dikembangkan kedepannya.

c. Menilai sejauh mana perubahaan yang dilakukan berpengaruh terhadap kinerja. Mengevaliasi kembali apakah perubahaan tersebut sesuai dengan tujuan bisnis yang ditetapkan.

\section{Kesimpulan}

Dari hasil pengukuran pada sistem pendukung pengambilan keputusan (DSS) di UNIVERSITAS $X$ yang dilakukan untuk level 1 sampai dengan level 5 pada dengan menggunakan COBIT 4.1 Process Assessment. Level 1 memiliki ketercapaian sebesar 60\% yang berarti skala ketercapaian diposisi Largely Achieved, Level 2 memiliki ketercapaian sebesar $59 \%$ yang berarti skala ketercapaian diposisi Largely Achieved, Level 3 memiliki ketercapaian sebesar $60 \%$ yang berarti skala ketercapaian diposisi Largely Achieved, Level 4 memiliki ketercapaian sebesar $61 \%$ yang berarti skala ketercapaian diposisi Largely Achieved, Level 5 memiliki ketercapaian sebesar 60\% yang berarti skala ketercapaian diposisi Largely Achieved.

Berdasarkan standar yang ada dalam COBIT 4.1 Process Assessment Model, tata kelola sistem pendukung pengambilan keputusan (DSS) di UNIVERSITAS X (Universitas Komputer Indonesia) 
telah mencapai tingkat kapabilitas level 1. Karena pada sebuah proses dapat dinyatakan mencapai tingkatan kapabilitas tertentu apabila seluruh atribut yang ada pada tingkat tersebut memiliki rating "Fully Achieved" atau "Largely Achieved", dengan seluruh atribut pada tingkat di bawahnya memiliki rating "Fully Achieved" [Ducan, 2002].

Rekomendasi yang akan diberikan dibuat kedalam dua tahan. Tahap pertama didalamnya memberikan rekomendasi perbaikan untuk permasalahaan yang sedang terjadi, sedangkan rekomendasi perbaikan untuk tahap kedua dibuat untuk meningkatkan level kapabilitas proses dari sistem pendukung pengambilan keputusan (DSS). Peningkatan level ini bertujuan untuk memperbaiki kapabilitas proses lainnya, dengan adanya peningkatan kapabilitas proses diharapkan kinerja sistem pendukung pengambilan keputusan akan lebih baik dan permasalahaan yang kemungkinan muncul dimasa yang akan datang akan tertanggulangi dari sekarang.

Tujuan dari peningkatan proses kapabilitas IT adalah meningkatkan kepampuan IT dalam mendukung proses bisnis. Pada penelitian ini proses bisnis yang dimaksud adalah pelayanan sistem pendukung keputusan. Ketika level kapabilitas proses IT lebih baik maka kemampuan IT dalam mendukung pelayanan sistem pendukung pengambilan keputusan akan lebih baik sehingga kinerja dari DSS akan lebih maksimal.

\section{Daftar Pustaka}

Amrul, Sadat S \& Hardi, Enny. (2010)." Pengaruh Organizational Learning Dan It Capability Terhadap Financial Performance". JAAI Volume 14 NO. 1, Juni 2010: 87-99

Bharadwaj AS. (2000)."A Resource-based Perspective on Information Technology Capability and Firm Performance: An Empirical Investigation". MIS Quarterly, 24 (1), 169-196

British Standard: ISO/IEC 15504, Software Engineering - Process Assessment, Part 2: Performing an Assessment, British Standard, 2003.

British Standard: ISO/IEC 15504, Information Technology - Process Assessment, Part 3: Guidance on Performing an Assessment, British Standard, 2004.

Guldentops, E. (2003), "Maturity Measurement - First the Purpose, Then the Method", Information Systems Control Journal, Vol. 4.

Hartanto, Indra Dwi \& Tjahyanto, Aries." Analisa Kesenjangan Tata Kelola Teknologi Informasi Untuk Proses Pengelolaan Data Menggunakan Cobit (Studi Kasus Badan Pemeriksa Keuangan Republik Indonesia)". Surabaya: Teknologi Sepuluh Nopember.

ISACA, COBIT ${ }^{\circledR}$ Assessment Process (CAP): COBIT ${ }^{\circledR} 4.1$ Process Assessment Model, IL, USA: ISACA, 2011.
Isnaini, Herdita Fajar dkk. (2013). "Makalah Komputer dan Teknologi Informasi Sistem Pendukung Keputusan". Yogyakarta: Universitas Negeri Yogyakarta.

King, W., dan Teo, T. (1996). "Key Dimensions of Facilitors and Inhibitors for the Strategic Use of Information Technology". Journal of Management of Information Systems, 12 (4), 3553

Komalasari, Reny. (2011)." Pengukuran Keselarasan Tujuan Teknologi Informasi Dan Tujuan Bisnis Universitas Narotama Surabaya Ditinjau Dari Perspektif Proses Bisnis/Internal Menggunakan Standar Cobit 4.1.". Proposal Tugas Akhir terpublikasi. Surabaya: Universitas Narotama.

Kothari, C.R. (2004). "Research Methodology: Methods and Techniques". New Delhi: New Age International (P) Ltd., Publishers.

Marina, Ade Putri \& Kridanto, Surendro. (2012)." Perancangan Model Kapabilitas Proses Pengelolaan Sumber Daya Teknologi Informasi". Volume 1, Number 2, Juli 2012 Jurnal Sarjana Institut Teknologi Bandung Bidang Teknik Elektro dan Informatika, Bandung : Institut Teknologi Bandung.

Renaud, Paul E. and Sonia D. Bot. (2012)." Enabling Process Alignmentfor IT Entrepreneurship". Chinese Proverb.

Richardson, VJ, Subramani, M, dan Zmud R.W. (2003)."Benefiting from Information Technology Investments: the Role of IT Conversion Capability". Second Round Review at MIS Quarterly.

Schreyögg, G \& Kliesch-Eberl, M 2007, “How dynamic can organizational capabilities be? Towards a dual-process model of capability dynamization", Strategic Management Journal, vol. 28, no. 9, p. 913.

Suharsimi Arikunto. (2010)."Penelitian Tindakan untuk Guru, Kepala Sekolah \& Pengawas". Yogyakarta: Aditya Media.

S. P. Duncan, “Making Sense of ISO 15504 (And SPICE)," 2002.

Teece, DJ, Pisano, G \& Shuen, A 1997, "Dynamic capabilities and strategic management", Strategic Management Journal vol. 18, no. 7, p. 509.

The IT Governance Institute, COBIT 4.1: Framework, Control Objectives, Management Guidelines, Maturity Models, IL, USA: IT Governance Institute, 2007.

Weill, Peter and Ross, Jeanne W. (2004), "IT Governance: How Top Performers Manage IT Decision Rights for Superior Result". Harvard Business School Press, Boston.

Zhang, M., dan McCullough, J. (2002). "Effect of Learning and Information Technology Capability on Business Performance". http://blake-montclair.edu 